\title{
Specific T-cell immunity against Ki-ras peptides in patients with pancreatic and colorectal cancers
}

\author{
Y Shono', H Tanimura', M Iwahashi', T Tsunoda', M Tani', H Tanaka', K Matsuda' and H Yamaue*,' \\ 'Second Department of Surgery, Wakayama Medical University, School of Medicine, 8 I I I Kimiidera, Wakayama 64 I-85 I0, Japan
}

\begin{abstract}
Mutations of codon 12 in the Ki-ras gene are frequently found in pancreatic and colorectal cancers. It has been demonstrated that human T-cells have the potential to recognise tumours expressing mutated ras-derived peptides. However, it remains unclear whether T-cells from a given individual can recognise the mutant peptides, which are expressed in that individual's tumour tissues. Mutations of the Ki-ras oncogene were analysed by the mutant-allele-specific amplification (MASA) method in pancreatic and colorectal tumour tissues, and T-cell responses against mutated Ki-ras-derived peptides were measured by $\left[{ }^{3} \mathrm{H}\right]$ thymidine incorporation and IFN- $\gamma$ production assays. Specific T-cell responses against Ki-ras-products were found in cancer patients, whereas no immune response was observed in normal individuals $(P<0.0 \mathrm{I})$. Six of the eight pancreatic cancer patients $(75 \%)$ and nine of 26 colorectal cancer patients (35\%) had T-cell responses to mutated Ki-ras-derived-peptides. T-cell response in a given individual cannot recognise the same mutated ras peptide, which is expressed in that individual's tumour tissues. However, pancreatic and colorectal cancer patients have T-cell immunity against Ki-ras-peptides, and this provides potential target for cancer immunotherapy.

British Journal of Cancer (2003) 88, 530-536. doi:10.1038/sj.bjc.6600697 www.bjcancer.com
\end{abstract}

(C) 2003 Cancer Research UK

Keywords: mutant p2I; T-cells; peptide vaccination; pancreatic cancer; colon cancer

\begin{abstract}
Malignant transformation is commonly associated with the acquisition of defined and characteristic mutations of cancerrelated genes (Marx, 1989). In many circumstances, the mutations result in the expression of aberrant proteins that disrupt the normal regulation of cell growth and differentiation (Fearon and Vogelstein, 1990). Several tumour antigens have been identified and the aberrant proteins capable of inducing tumour-specific immune responses have been studied in terms of their specificity and their putative functional roles in oncogenesis (van der Bruggen et al, 1991; Kawakami and Rosenberg, 1997; Nestle et al, 1998; Rosenberg et al, 1998).

Somatic mutations of the ras genes have been shown to be involved in the malignant processes in tumorigenesis. Ki-ras mutations are found in approximately $90 \%$ of pancreatic adenocarcinomas and $40 \%$ of colorectal adenocarcinomas (Bos et al, 1987; Almoguera et al, 1988; Bos, 1989) These mutations convert the ras protein to a constitutively active protein, resulting in stimulation of cell proliferation. In pancreatic and colorectal cancer patients, mutated Ki-ras products are attractive targets for cancer immunotherapy since they are not commonly expressed in normal tissue and since T-cells' immune system can detect single amino-acid substitutions (Fossum et al, 1993).
\end{abstract}

In the present study, we have tested whether T-cells specific for mutant ras peptides from a given individual with pancreatic or

*Correspondence: Dr H Yamaue;

E-mail: yamaue-h@wakayama-med.ac.jp

Revised 25 June 2002; accepted 9 October 2002 colorectal cancer can recognise the same peptide expressed in that individual's tumour tissues.

\section{PATIENTS AND METHODS}

\section{Patients}

In total, 14 patients with pancreatic cancer, 26 patients with colorectal cancer, and six healthy volunteers from Wakayama Medical University Hospital were enrolled in this study. Informed consent for the studies was obtained from all the patients in accordance with the guideline of the Ethics Committee on Human Research, Wakayama Medical University.

\section{Analysis of Ki-ras mutations in codon 12}

Genomic DNA was isolated from resected tumours of pancreatic and colorectal cancer patients in operation using a DNA extraction kit (QIAGEN). Approximately $3 \mathrm{~mm}^{3}$ of tumour materials were homogenised, and DNA extraction was performed according to the manufacturer's recommendations.

To confirm the sensitivity of the mutant-allele-specific-amplification (MASA) method, DNA extracted from two pancreatic cancer cell lines (PANC-1, BXPC3) and two lung cancer cell lines (A549, LU65) was examined for mutations of Ki-ras codon 12. It has been reported that PANC-1 has a Ki-ras 12 mutation from GGT (Gly) to GAT (Asp), BXPC3 has a wild-type allele of Ki-ras 12, A549 has a GGT (Gly) to (Ala) and LU65 has a GGT (Gly) to (Leu) mutation (Valenzuela and Groffen, 1986; Suwa et al, 1994). 


\section{MASA method}

We analysed Ki-ras mutations using the MASA method. This method can recognise point mutations corresponding to the $3^{\prime}$-end nucleotides of forward primers that have mutant $3^{\prime}$-end sequences (Takeda et al, 1993).

The Ki-ras mutations in codon 12 were confirmed by direct sequencing of the above PCR products.

\section{Peptides}

The amino-acid sequences of the wild-type and mutant Ki-ras 18mer peptides used are shown in Table 1. The synthesis of rasderived peptides was based on the sequence information provided by Dr MA Cheever (Qin et al, 1995), and purchased from TAKARA Corp., Japan. The purity of Ki-ras peptides are more than $93 \%$.

\section{Cell preparation and media}

Blood samples $(20-40 \mathrm{ml})$ from each cancer patient and from normal individuals were obtained with informed consent. Peripheral blood mononuclear cells (PBMC) were isolated by density centrifugation over Ficoll-Paque (Pharmacia, Uppsala, Sweden). Cells were washed twice and adjusted to $2 \times 10^{6} \mathrm{cells} \mathrm{ml}^{-1}$ in RPMI-1640 (GIBCO) containing 7\% heat-inactivated autoserum, $10 \mathrm{mM}$ L-glutamine, $200 \mathrm{U}$ of penicillin-streptomycin $\mathrm{ml}^{-1}$, and $25 \mathrm{~mm}$ 2-mercaptoethanol.

\section{Lymphocyte proliferation assay}

Cell aliquots suspensions $(100 \mu \mathrm{l})$ at $2 \times 10^{5}$ cells ml $^{-1}$ were plated into each well of round-bottomed 96-well microtiter plates (Corning, Corning, NY, USA). PBMC were incubated without peptides, or with $100 \mu \mathrm{l}$ of ras peptide $\left(100 \mu \mathrm{g} \mathrm{ml}^{-1}\right)$, or with $100 \mu \mathrm{l}$ of phytohaemagglutinin (PHA, $5 \mu \mathrm{g} \mathrm{m}^{-1}$ ). The plates were incubated in a humidified atmosphere under $5 \% \mathrm{CO}_{2} / 95 \%$ air at $37^{\circ} \mathrm{C}$ for $96 \mathrm{~h}$ and then incubated for $8 \mathrm{~h}$ with $1 \mu \mathrm{Ci}(35 \mathrm{Mbq})$ of $\left[{ }^{3} \mathrm{H}\right]$ thymidine well ${ }^{-1}$. Cells were then harvested, and thymidine incorporation was determined by liquid scintillation counting.

Each determination of proliferation was carried out in at least five replicated wells. The stimulation index (SI) was calculated by dividing the c.p.m. (mean) obtained from each group by the c.p.m. (mean) from autologus PBMC incubated without peptides. A positive proliferative response was defined as an SI greater than 2 (Qin et al, 1995).

\section{Interferon- $\gamma($ IFN- $\gamma)$ production assay}

Aliquots $(2 \mathrm{ml})$ of cell suspensions at $2 \times 10^{6}$ cells ml $^{-1}$ were plated into each well of flat-bottomed, 48-well microtiter plates (Falcon No.3078). PBMC were incubated without peptides (no stimulation), or were stimulated with Ki-ras peptide $\left(50 \mu \mathrm{g} \mathrm{ml}^{-1}\right)$ or PHA $\left(5 \mu \mathrm{g} \mathrm{ml}^{-1}\right)$.

The plates were incubated in a humidified atmosphere of $5 \%$ $\mathrm{CO}_{2} / 95 \%$ air at $37^{\circ} \mathrm{C}$. Primary cultures were replenished with $1 \mathrm{ml}$ of fresh human interleukin-2 (IL-2)-containing inactivated autoserum medium $\left(20 \mathrm{IU} \mathrm{ml}^{-1}\right)$ on days 5,10 and 15 , and were stimulated with the same Ki-ras peptide $\left(50 \mu \mathrm{g} \mathrm{ml}^{-1}\right)$ and with

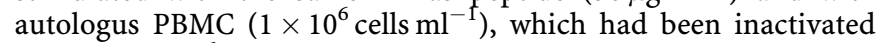
with $50 \mu \mathrm{g} \mathrm{ml}^{-1}$ of mitomycin $\mathrm{C}$ at $37^{\circ} \mathrm{C}$ for $30 \mathrm{~min}$, as antigenpresenting cells, on day 10 . Cultures were then continued for 20 days. Aliquots $(1 \mathrm{ml})$ of the supernatants of these cultures were collected on days 5 (sup. 1), 10 (sup. 2), 15 (sup. 3), and 20 (sup. 4). The supernatants were analysed for secretion of IFN- $\gamma$ using an enzyme-linked immunosorbent assay (ELISA) kit (Endogen, Boston, MA, USA). The results were expressed in $\mathrm{IU} \mathrm{ml}^{-1}$. A positive response to a Ki-ras peptide was defined as production of at least $4 \mathrm{IU} \mathrm{ml}^{-1}$ of IFN- $\gamma$, which is four times greater than the
Table I Wild-type and mutated Ki-ras peptides (18-mers) employed in this study

\begin{tabular}{|c|c|c|}
\hline Peptide name & Amino-acid sequence & Point mutation \\
\hline \multicolumn{3}{|l|}{ Wild-type peptide } \\
\hline Ras G $12(p 4-21)$ & YKLWWGAGGVGKSALTI & (GGT) \\
\hline \multicolumn{3}{|l|}{ Mutated peptides } \\
\hline Ras V $12(p 4-21)$ & YKLWWGAVGVGKSALTI & (GTT) \\
\hline Ras C I2 (p4-2l) & YKLWWGAC̄GVGKSALTI & $(\mathrm{T} \overline{\mathrm{G}} \mathrm{T})$ \\
\hline Ras D $12(p 4-21)$ & YKLWWGĀ̄ GVGKSALTI & $(\overline{\mathrm{G}} \mathrm{A} T)$ \\
\hline
\end{tabular}

production by control, in at least one of the four supernatants tested at least one time.

The HLA-DR and -DQ loci of healthy volunteers, pancreatic cancer patients and colorectal cancer patients were analysed, and the relationships between the HLA-DR and -DQ loci and positive responses of cancer patients to peptides were investigated.

\section{RESULTS}

\section{Ki-ras mutation in cancer patients}

Table 2 shows the results of analysis of $\mathrm{Ki}$-ras codon 12 mutations in pancreatic and colorectal cancer tissues by the MASA method. $K i$-ras mutations were found in nine of $14(64 \%)$ pancreatic cancer tissues and six of $26(23 \%)$ colorectal cancer tissues. The sort of Kiras codon 12 mutation in tumours was aspartic acid (67\%), valine $(22 \%)$ and cysteine $(11 \%)$ with pancreatic cancer patients, and aspartic acid (50\%) and valine (50\%) with colorectal cancer patients.

\section{Lymphocyte proliferative assay}

The primary lymphocyte response to Ki-ras peptides was determined in six patients with pancreatic cancer and 11 patients with colorectal cancer. There was no enhancement of proliferation in response to $\mathrm{Ki}$-ras peptides in the primary responses of any of the patients including Ki-ras mutations in their own tumours. Data were not shown.

\section{IFN- $\gamma$ production assay}

IFN- $\gamma$ production of T-cells as a consequence of Ki-ras-derived peptide stimulation was investigated in six healthy volunteers, eight patients with pancreatic cancer and 26 patients with colorectal cancer. None of the healthy volunteers had a positive immune response against Ki-ras peptides.

\section{T-cell responses to Ki-ras peptides can be detected in} pancreatic cancer patients

Six of the eight pancreatic cancer patients $(75 \%)$ had positive responses to wild-type or mutated $\mathrm{Ki}$-ras peptides (Figure 1). Pancreatic cancer cases 1,10 and 9 had positive responses to mutated Ki-ras V12 peptide. Pancreatic cancer case 11 had positive response to wild-type Ki-ras peptide. Pancreatic cancer case 12 had positive response to Ki-ras D12 peptide. Pancreatic cancer case 7 had a positive response to wild-type and Ki-ras D12 peptides. Kiras mutations were analysed in pancreatic cancer tissues from the patients, and results showed that cases 1 and 11 had D12 mutations, case 9 had a C12 mutation, case 7 had a V12 mutation, and cases 10 and 12 had no mutation. 
Table 2 Ki-ras point mutations at position 12 in pancreatic and colorectal cancer tissues

\begin{tabular}{llclll}
\hline Pancreatic cancer & Mutation & Colorectal cancer & Mutation & & Mutation \\
\hline 1 & Gly $\rightarrow$ Asp & 1 & Gly $\rightarrow$ Asp & 14 & Wild type \\
2 & Gly $\rightarrow$ Asp & 2 & Gly $\rightarrow$ Asp & 15 & Wild type \\
3 & Gly $\rightarrow$ Asp & 3 & Gly $\rightarrow$ Asp & 16 & Wild type \\
4 & Gly $\rightarrow$ Asp & 4 & Gly $\rightarrow$ Val & 17 & Wild type \\
5 & Gly $\rightarrow$ Asp & 5 & Gly $\rightarrow$ Val & 18 & Wild type \\
6 & Gly $\rightarrow$ Asp & 6 & Gly $\rightarrow$ Val & 19 & Wild type \\
7 & Gly $\rightarrow$ Val & 7 & Wild type & 20 & Wild type \\
8 & Gly $\rightarrow$ Val & 8 & Wild type & 21 & Wild type \\
9 & Gly $\rightarrow$ Cys & 9 & Wild type & 22 & Wild type \\
10 & Wild type & 10 & Wild type & 23 & Wild type \\
11 & Wild type & 11 & Wild type & 24 & Wild type \\
12 & Wild type & 12 & Wild type & 25 & Wild type \\
13 & Wild type & 13 & Wild type & 26 & Wild type \\
14 & Wild type & & & & Wild type \\
& $9 / 14$ (64\%) & & & & $6 / 26$ (23\%)
\end{tabular}

Gly=glycine; Val=valine; Asp=aspartic acid; Cys=cysteine.
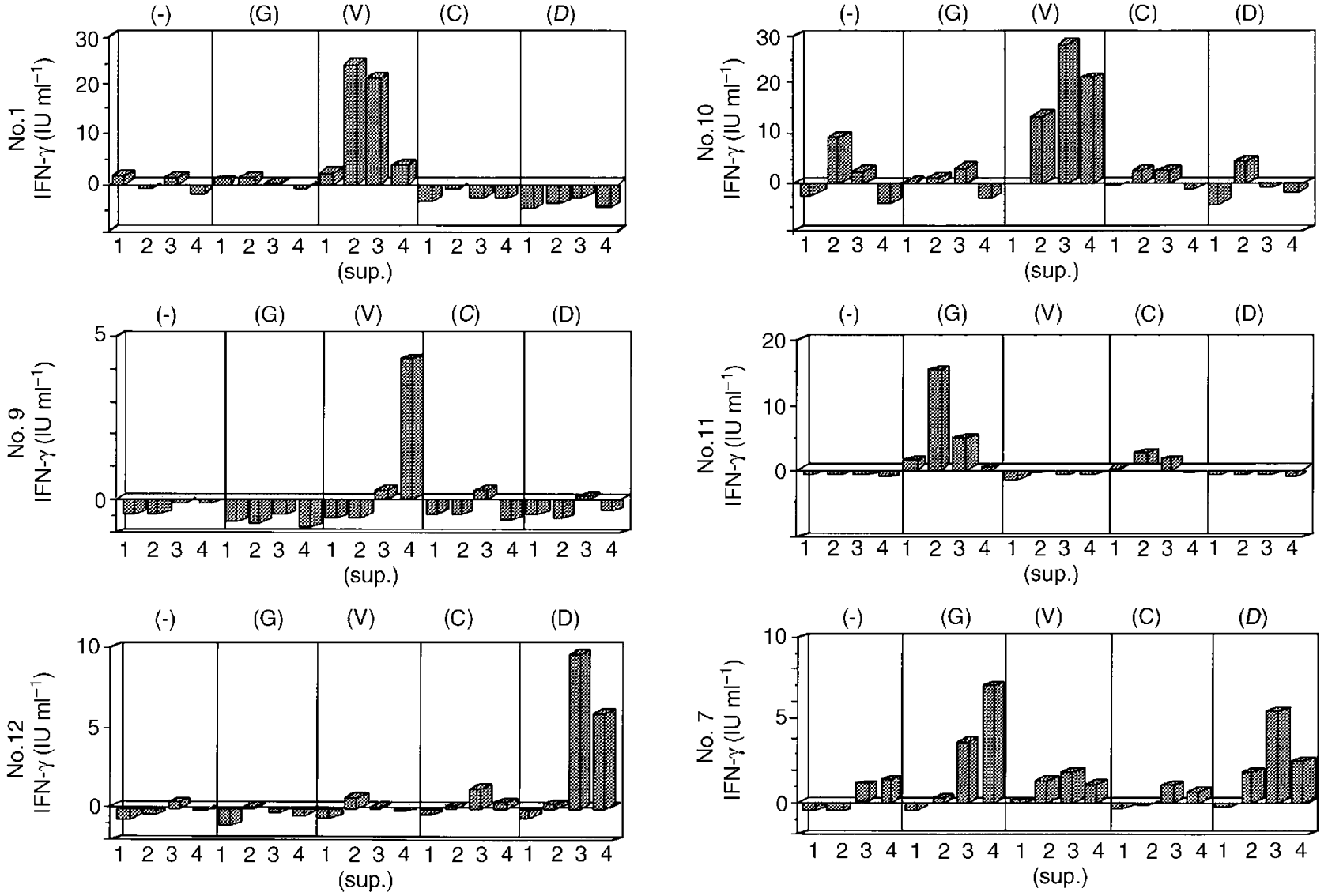

$(-)$ :negative control

Figure I IFN- $\gamma$ production in T-cell response against Ki-ras peptides in pancreatic cancer patients. IFN- $\gamma$ production in pancreatic cancer patients: (I) Kiras mutation (D) (DR4, 9; DQ3,4); ( I0) Ki-ras mutation (-) (DR4, 9; DQ3, 4); (9) Ki-ras mutation (C) (DR9, I2 DQ3); (I I) Ki-ras mutation (D); (I2) Ki-ras mutation (-) (DR9, 8; DQI, 3) (7) Ki-ras mutation (V) (DR8; 2 DQI). The numbers (I-4) of supernatants indicate the period of exposure of T-cells exposed to Ki-ras peptides. Supernatants I, 2, 3 and 4 were collected on days 5, 10, 15 and 20 after primary stimulation, respectively.

\section{T-cell responses to Ki-ras peptides can be detected in colorectal cancer patients}

Nine of 26 colorectal cancer patients (35\%) had positive responses to wild-type or mutated Ki-ras peptides (Figure 2). Colorectal cancer cases 7, 1 and 2 had positive responses to mutated Ki-ras D12 peptide. Colorectal cancer cases 8 and 9 had positive responses to wild-type Ki-ras C12 peptide. Colorectal cancer cases 4 and 12 had positive response to wild-type peptide. Colorectal cancer case 11 had positive response to mutated Ki-ras C12 and 

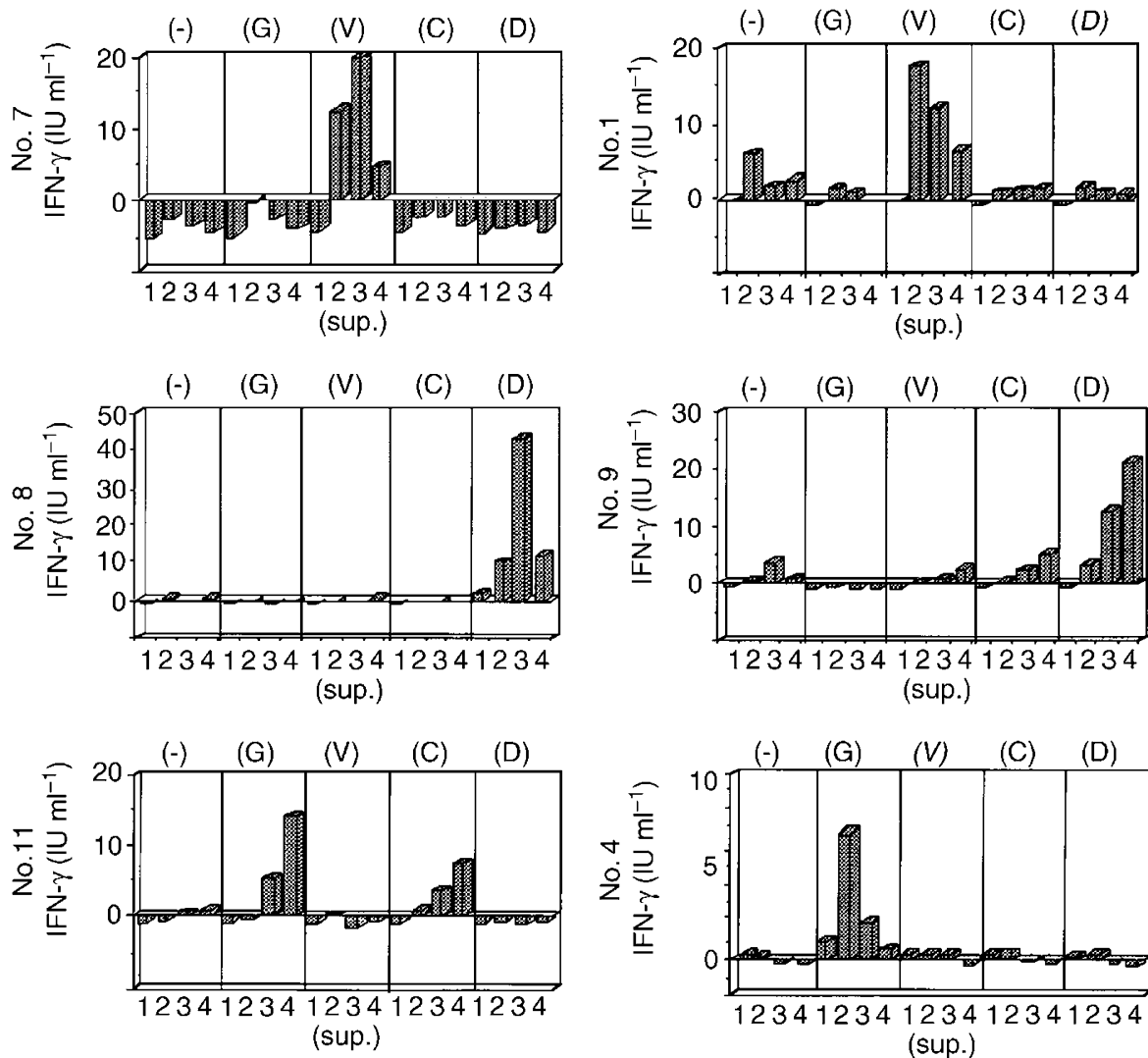

$(-)$ :negative control

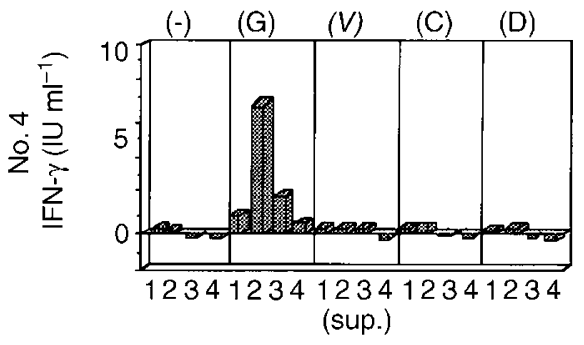

(sup.)
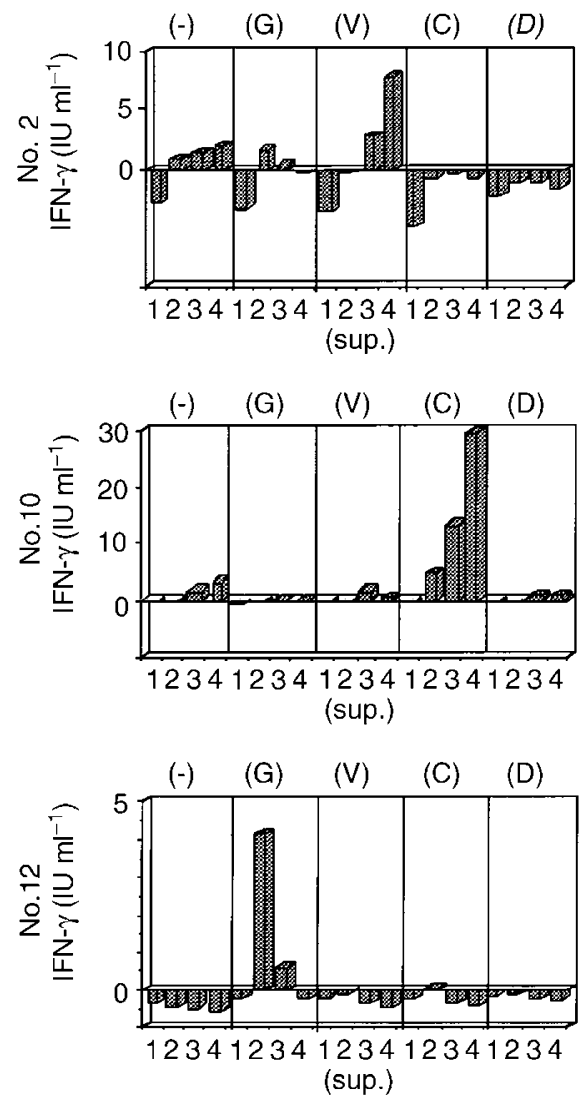

Figure 2 IFN- $\gamma$ production in T-cell response against Ki-ras peptides in colorectal cancer patients. IFN- $\gamma$ production in colorectal cancer patients: (7) Ki-ras mutation (-) (DR4, 6; DQI, 4) (I) Ki-ras mutation (D) (DRI, 8; DQI) (2) Ki-ras mutation (D); (8) Ki-ras mutation (-) (DR8, I2; DQ3, 4) (9) Ki-ras mutation (-) (DR2,6; DQ I); (I0) Ki-ras mutation (-) (DR2,6; DQI,3); (I I) Ki-ras mutation (-) (DRI, 4; DQ I, 3) ; (4) Ki-ras mutation (V) (DR8; DQ I, 3); (I2) Ki-ras mutation (-) (DR6; 9 DQI). The numbers $(1-4)$ of supernatants indicate the period of exposure of T-cells exposed to Ki-ras peptides. Supernatants 1, 2, 3 and 4 were collected on days 5, 10, 15 and 20 after primary stimulation, respectively.

wild-type peptides. Ki-ras mutations were analysed in colorectal cancer tissues from the patients, and results showed that cases 1 and 2 had D12 mutations, case 4 had a C12 mutation, and cases 7 12 had no mutation.

Thus, specific T-cell immunity against Ki-ras products was present in cancer patients, whereas no immune response was observed in healthy volunteers $(P<0.01)$. Six of the eight pancreatic cancer patients and nine of the 26 colon cancer patients had a response to Ki-ras peptides. However, the T-cells immunity of a given individual could not recognise the mutant ras peptide that was expressed in the tumour tissues of that individual (Table 3).

\section{Relationship between HLA-DR and -DQ loci and positive response against Ki-ras peptides in cancer patients}

HLA-DR and -DQ of healthy volunteers, pancreatic cancer patients, and colorectal cancer patients were examined. Among five patients who had positive responses to Ki-ras V12 peptide, three patients had DR4, DR9, DQ3 or DQ4 locus. Among four patients who had positive responses to Ki-ras D12 peptide, three patients had DR8 or DQ1 locus. The two patients who had positive responses to Ki-ras $\mathrm{C} 12$ peptide were found to have DQ1 or DQ3 locus. Among four patients who had positive responses to wild-type peptide, two patients had DQ1 or DQ3 locus (Table 4).

\section{DISCUSSION}

Activating amino-acid substitutions impair the intrinsic GTPase activity of the ras protein and generate constitutively activated signal complexes with transforming activity. Point mutations in ras genes have been found in a wide variety of human and murine cancers, especially in human pancreatic cancers (90\%) and human colorectal cancers (45\%) (Bos et al, 1987; Almoguera et al, 1988; Bos, 1989).

A large fraction of human cancers harbour point mutations in the ras gene at codon 12, in which the normal residue is substituted by a Val, Asp or Cys residue. From an immunological perspective, these determinants may represent highly specific epitopes for T-cell (CD4+ and/or CD8+) recognition in cancer immunotherapy (Tsang et al, 1994; Fossum et al, 1995). Evaluation of point-mutated ras as a T-cell epitope could be determined biologically using short synthetic peptides that precisely correspond to the altered sites.

Several laboratories established approaches in both murine and human systems to evaluate point-mutated ras p21 oncogene products as potential tumour-specific targets and to characterise the resulting cellular immune responses.

Studies using those system have shown that mutant ras protein is able to serve as a tumour-specific antigen (Peace et al, 1991a; Cheever et al, 1995). T-cells from animals immunised by ras peptides can lyse cells transformed to express the ras products with the same mutation in animal models (Peace et al, 1991b). 
Table 3 T-cell response against K-ras peptides

\begin{tabular}{|c|c|c|c|c|c|c|c|c|c|}
\hline \multicolumn{2}{|c|}{ Healthy volunteers } & \multirow{2}{*}{\multicolumn{3}{|c|}{ Peptides (which sort of response) }} & \multicolumn{2}{|c|}{$\begin{array}{l}\text { Colorectal cancer } \\
\text { patients }\end{array}$} & \multirow{3}{*}{$\begin{array}{l}\text { Tumor tissue } \\
\text { Ki-ras mut. } \\
\text { Wild type }\end{array}$} & \multirow{2}{*}{\multicolumn{2}{|c|}{$\begin{array}{l}\text { Peptides } \\
\text { (which sort of } \\
\text { response) }\end{array}$}} \\
\hline \multirow{2}{*}{$\frac{\text { No. }}{\text { | }}$} & \multirow{2}{*}{$\begin{array}{l}\text { DR, DQ Locus } \\
\text { DR4 DQ4, } 7\end{array}$} & & & & \multirow{2}{*}{$\frac{\text { No. }}{7}$} & \multirow{2}{*}{$\begin{array}{l}\text { DR, DQ locus } \\
\text { DR4, } 6 \text { DQI, } 4\end{array}$} & & & \\
\hline & & None & (T-cell re & se $0 / 10(0 \%))$ & & & & Val & \\
\hline 2 & DR8, $10 \mathrm{DQ} 1,9$ & None & & & I & DRI, $8 \mathrm{DQ}$ & Gly $\rightarrow$ Asp & Val & \\
\hline 3 & DR4, 8 DQI, 4 & None & & & 2 & NT & Gly $\rightarrow$ Asp & Val & \\
\hline 4 & DR9, 8 DQ3, I & None & & & 8 & DR8, 12 DQ3, 4 & Wild type & Asp & \\
\hline 5 & DR4, 9 DQ3, 4 & None & & & 9 & DR2, 6 DQI & Wild type & Asp & \\
\hline 6 & DR8, 9 DQI, 3 & None & & & 10 & DR2, 6 DQI, 3 & Wild type & Cys & \\
\hline 7 & DRI0, 2 DQI & None & & & | | & DRI, 4 DQI, 3 & Wild type & Gly, Cys & \\
\hline 8 & DR4, 9 DQ3, 4 & None & & & 4 & DR8 DQI, 3 & $\mathrm{Gly} \rightarrow \mathrm{Val}$ & Gly & \\
\hline 9 & DR2, 8 DQI, 6 & None & & & 12 & DR6, 9 DQI, 3 & Wild type & Gly & \\
\hline 10 & DR8, 4 DQI, 4 & None & & & 3 & DR6, 8 DQI & Gly $\rightarrow$ Asp & None & \\
\hline \multicolumn{2}{|c|}{ Pancreatic cancer patients } & \multirow{2}{*}{$\begin{array}{l}\text { Tumor tissue } \\
\text { Ki-ras mut. }\end{array}$} & \multirow{2}{*}{\multicolumn{2}{|c|}{$\begin{array}{l}\text { Peptides (which sort } \\
\text { of response) }\end{array}$}} & 7 & NT & $\mathrm{Gly} \rightarrow \mathrm{Val}$ & None & \\
\hline No & DR, DQ Locus & & & & 6 & DRI, 4 DQI, 3 & Gly $\rightarrow$ val & None & \\
\hline 1 & DR4, 9 DQ3, 4 & Gly $\rightarrow$ Asp & Val & & 13 & NT & Wild type & None & \\
\hline 10 & DR4, 9 DQ3, 4 & Wild type & Val & (T-cell & 14 & DR4, 8 DQI, 4 & Wild type & None & \\
\hline 9 & DR9, 12 DQ3 & Gly $\rightarrow$ Cys & Val & response 6/8 & 15 & DR2, 4 DQI, 2 & Wild type & None & \\
\hline|| & $N T^{\mathrm{a}}$ & Wild type & Gly & $(75 \%) 2)$ & 16 & DRI, 6 DQI, 3 & Wild type & None & \\
\hline 12 & DR9, 8 DQI, 3 & Wild type & Asp & & 17 & DR8, 9 DQI, 3 & Wild type & None & \\
\hline 7 & DR8, 2 DQI & $\mathrm{Gly} \rightarrow \mathrm{Val}$ & Asp. Gly & & 18 & DR4, 8 DQI, 4 & Wild type & None & \\
\hline 2 & DRI0,9 DQI, 3 & Gly $\rightarrow$ Asp & None & & 20 & DR4, 9 DQ3, 4 & Wild type & None & \\
\hline \multirow[t]{6}{*}{13} & DR4, 9 DQ3, 4 & Wild type & None & & 21 & DR4, 6 DQI, 4 & Wild type & None & (T-cell \\
\hline & & & & & 22 & DR4, 6 DQI, 4 & Wild type & None & response \\
\hline & & & & & 23 & DRI, 4 DQI, 3 & Wild type & None & $9 / 26(35 \%) *)$ \\
\hline & & & & & 24 & DR2, 4 DQI, 4 & Wild type & None & \\
\hline & & & & & 25 & DR6, 8 DQI, 3 & Wild type & None & \\
\hline & & & & & 26 & NT & Wild type & None & \\
\hline
\end{tabular}

${ }^{a} N T=$ not tested; Gly=glycine; Val=valine; Asp=aspartic acid; Cys=cysteine. ${ }^{*} P<0.001$, compared to normal individuals.

The observation that ras products can be immunogenic in mice suggested that similar T-cell responses might be present in humans (Peace et al, 1991a). In vitro stimulation of human T-cells from some normal individuals or cancer patients with mutant ras peptides results in the expansion of CD4+ and CD8+ precursors, which may exhibit cytotoxicity against autologous or MHCmatched, antigen-bearing target cells (Fossum et al, 1994b; Juretic et al, 1996). In addition, humoral responses specific for ras products have been observed in colorectal cancer patients (Takahashi et al, 1995).

Other studies showed that the human T-cells can recognise peptides that span the mutated segment of the ras protein and that the ras peptide-specific T-cells can respond to ras protein containing the same substitution (Jung and Schluesener, 1991; Gedde-Dahl et al, 1992; Fossum et al, 1994a; Qin et al, 1995). Previous studies have identified that ras mutation-specific memory T-cells in only two human cancer patients with follicular thyroid cancer and colorectal cancer (Gedde-Dahl et al, 1992; Fossum et al, $1994 a, b)$. In both of these cases, the corresponding ras mutation could not be detected in the available tumour biopsy samples.

However, it remains unclear whether T-cells can recognise the same mutated peptides that are expressed in tumour tissues from the same individual tissue. We first analysed the correlation between the peptides that induce T-cell response against $\mathrm{Ki}$-ras peptides and the Ki-ras mutations in pancreatic and colorectal cancer tissues.

We are not able to show that T-cells can recognise the mutated ras peptide that is expressed in the tumour cells from the same individuals.

To assess the immune response against Ki-ras peptides in patients with pancreatic and colorectal cancer patients, primary proliferative response assays and IFN- $\gamma$ production assays were done. No effect of these peptides could be detected using the primary proliferative response assay, because of the low immunogenicity of the Ki-ras products. On the other hand, it was possible to detect a Ki-ras response by twice stimulation with Ki-ras peptides and stimulation by IL- 2 in an IFN- $\gamma$ production assay. The stimulation of such a low concentration of IL-2 is intended to suppress the secretion of IFN- $\gamma$ from other cell sources, including the activation of natural killer cells. The purpose of IFN- $\gamma$ production assays is to determine which peptide is significant for the T-cell activation, and actual concentration is not calculated. We used the 18-mer peptides that can bind to class II molecule, but not to class I molecule. Therefore, the CD4+ cells might be related in this study. However, the primary culture in the IFN- $\gamma$ production assay contains antigen-presenting cells, so CD8+ cells may be contributed in this assay. T-cell immunity against Ki-ras peptides was detected at lower frequency in colorectal cancer patients than in pancreatic cancer patients. This suggested that the immunogenicity to ras products was recognised more strongly in pancreatic cancer patients who had a high frequency of ras mutations in their tumour tissue, but the T-cells did not recognise the 'correct' mutation. T-cells in the patients with pancreatic cancer may have been previously exposed to similar antigens in vivo.

We propose two possible reasons why T-cells from a given individual cannot recognise the same mutated ras peptide expressed in the tumour tissues of that individual.

First, the length of the peptides bound by MHC class II molecules are not strongly constrained. Therefore, the binding of peptides to MHC class II molecules is more promiscuous than the binding of peptides to MHC class I molecules. Peptides that bind to 
Table 4 Relation between HLA-DR and - DQ locus and positive response to peptides in cancer patient

\begin{tabular}{|c|c|c|c|c|c|c|c|c|c|c|c|}
\hline \multirow[b]{2}{*}{ Patient No. } & \multicolumn{2}{|c|}{ HLA } & \multirow{2}{*}{\multicolumn{5}{|c|}{ Mutation in tumour tissues }} & \multirow{2}{*}{\multicolumn{4}{|c|}{ Responding peptides }} \\
\hline & -DR Locus & -LR Locus & & & & & & & & & \\
\hline PI & DR4, 9 & DQ3, 4 & \multicolumn{5}{|c|}{ Gly $\rightarrow$ Asp } & \multicolumn{4}{|l|}{ Val } \\
\hline $\mathrm{Cl}$ & DRI, 8 & DQI & \multicolumn{5}{|c|}{ Gly $\rightarrow$ Asp } & \multicolumn{4}{|l|}{ Val } \\
\hline P9 & DR9, 12 & DQ3 & \multicolumn{5}{|c|}{ Gly $\rightarrow$ Cys } & \multicolumn{4}{|l|}{ Val } \\
\hline PIO & DR4, 9 & $\mathrm{DQ} 3,4$ & \multicolumn{5}{|c|}{ Wild type } & \multicolumn{4}{|l|}{ Val } \\
\hline C7 & DR4, 6 & DQI, 4 & \multicolumn{5}{|c|}{ Wild type } & \multicolumn{4}{|c|}{ Val } \\
\hline P7 & DR2, 8 & DQI & \multicolumn{5}{|c|}{ Gly $\rightarrow$ Asp } & \multicolumn{4}{|c|}{ Asp, Gly } \\
\hline C8 & DR8, 12 & DQ3, 4 & \multicolumn{5}{|c|}{ Wild type } & \multicolumn{4}{|l|}{ Asp } \\
\hline C9 & DR2, 6 & DQI & \multicolumn{5}{|c|}{ Wild type } & \multicolumn{4}{|l|}{ Asp } \\
\hline $\mathrm{P} 12$ & DR8, 9 & DQI, 3 & \multicolumn{5}{|c|}{ Wild type } & \multicolumn{4}{|l|}{ Asp } \\
\hline $\mathrm{ClO}$ & DR2, 6 & DQ1, 3 & \multicolumn{5}{|c|}{ Wild type } & \multicolumn{4}{|l|}{ Cys } \\
\hline $\mathrm{Cll}$ & DRI, 4 & DQI, 3 & \multicolumn{5}{|c|}{ Wild type } & \multicolumn{4}{|c|}{ Cys, Gly } \\
\hline C4 & DR8 & DQI, 3 & \multicolumn{5}{|c|}{ Gly $\rightarrow$ Val } & \multicolumn{4}{|c|}{ Gly } \\
\hline P7 & DR2, 8 & DQI & \multicolumn{5}{|c|}{ Gly $\rightarrow$ Asp } & & \\
\hline $\mathrm{Cl} 2$ & DR6, 9 & DQI, 3 & \multicolumn{5}{|c|}{ Wild type } & & & & \\
\hline $\mathrm{Cll}$ & DRI, 4 & DQI, 3 & & Vild type & & & & Gly, & & & \\
\hline & & & & & & & & & & & \\
\hline Peptide & Total no. & $\mathbf{I}$ & 2 & 4 & 6 & 8 & 9 & 12 & 1 & 3 & 4 \\
\hline Val & 5 & । & & $\underline{3}$ & 1 & 1 & 3 & । & 2 & $\frac{3}{2}$ & $\underline{3}$ \\
\hline Asp & 4 & & 2 & & 1 & 3 & $T$ & 1 & 3 & $\overline{2}$ & $T$ \\
\hline Cys & 2 & I & I & & 1 & & & & $\overline{2}$ & 2 & \\
\hline Gly & 4 & I & । & । & 1 & 2 & I & & $\underline{\overline{4}}$ & $\overline{3}$ & \\
\hline
\end{tabular}

$\mathrm{P}=$ pancreatic cancer patients; $\mathrm{C}=$ colon cancer patients.

MHC class II molecules are variable in length and their anchor residues lie at various distances from the end of the peptide (Rudensky et al, 1991; Rammensee et al, 1995; Hammer et al, 1994). In patients who respond to wild-type peptide, their anchor motif of class II molecule are considered to be similar to wild-type peptide.

Second, we speculate that tumour cells harbouring a mutation have been eliminated by the immune system in cancer patients. Kiras mutations are thought to occur as a relatively early event in the developmental sequence of colorectal adenocarcinoma (Vogelstein et al, 1988), and may therefore be expressed early on by most of the tumour cells. The cancer present at the time of biopsy may have progressed further, and may not harbour the same mutation because the cancer cells harbouring the earlier mutation were eliminated by the immune system in an early event of tumour development (Nakagawa et al, 1991).

It is suggested that $\mathrm{T}$-cells responding to synthetic 18 -mer Ki-ras peptides are restricted by HLA-DR or -DQ class II molecules. Ras p21 is an internally localised biosynthetic protein and is therefore potentially susceptible to the endogenous pathway of antigen processing and subsequent loading with MHC class I or II molecules. It is possible that point-mutated ras $\mathrm{p} 21$ proteins may be processed through an exogenous mechanism. In this regard, Harmer et al reported that point-mutated ras p21 proteins can be found in the external tumour microenvironment as well as in the plasma of tumour-bearing mice, and if so, may be available as exogenous antigens for endosomal processing by antigenpresenting cells and presentation to CD4+ T-cells (Harmer et al, 1991).

CD4+ T-cells are thought to play an important and central role in immunoregulation through the production and action of lymphokines. Accordingly, several peptide- or protein-based immunotherapy has great therapeutic potential for cancer patients whose tumours harbour point mutations in codon 12 of the ras $\mathrm{p} 21$ proto-oncogene.

\section{REFERENCES}

Almoguera C, Shibata D, Forrester K, Martin J, Arnheim N, Perucho M (1988) Most human carcinoma of the exocrine pancreas contain mutant c-Ki-ras genes. Cell 53: 549-554.

Bos JL (1989) Ras oncogenes in human cancer: a review. Cancer Res 49: $4682-4689$

Bos JL, Fearon ER, Hamilton SR, Verlaan de Vries M, van Boom JH, van der Eb AJ, Vogelstein B (1987) Prevalence of ras gene mutation in human colorectal cancer. Nature (Lond.) 327: 293-297

Cheever MA, Disis ML, Bernhard H, Chen W, Gralow JR, Hand SL, Huseby ES, Qin HL (1995) Immunity to oncogenic proteins. Immunol Rev 145: $33-59$
Fearon ER, Vogelstein B (1990) A genetic model for colorectal tumourigenesis. Cell 61: $759-767$

Fossum B, Breivik J, Meling GI, Gedde-Dahl T, Gaudernack G (1994a) A $\mathrm{Ki}$-ras 13GLY $\rightarrow$ ASP mutation is recognised by HLA-DQ7 restricted Tcells in a patient with colorectal cancer. Modifying effect of DQ7 on established cancers harbouring this mutation? Int $J$ Cancer 58: $506-511$

Fossum B, Gedde-Dahl III T, Breivik J, Eriksen JA, Gaudernack G (1994b) p21-ras-peptide-specific $\mathrm{T}$-cell responses in-patients with colorectal cancer. CD4+ and CD8+ T-cells recognised a peptide corresponding to a common mutation (13Gly $\rightarrow$ Asp). Int J Cancer 56: $40-45$ 
Fossum B, Gedde-Dahl T, Hansen T, Eriksen JA, Thorsby E, Gaudernack G. (1993) Overlapping epitopes encompassing a point mutation (12Gly $\rightarrow$ Arg) in p21 ras can be recognised by HLA-DR, -DP and -DQ restricted Tcells. Eur J Immunol 23: 2687-2689

Fossum B, Oslen AC, Thorsby E, Gaudernack G (1995) CD8+ T-cells from a patient with colon carcinoma, specific for mutant p21 ras-derived peptide $(\mathrm{GLY} 13<\mathrm{ASP})$, are cytotoxic, towards a carcinoma cell line harbouring the same mutation. Cancer Immunol Immunother 40: $165-172$

Gedde-Dahl III T, Spurkland A, Eriksen JA, Thorsby E, Gaudernack G (1992) Memory T-cells of a patient with follicular thyroid carcinoma recognise peptides derived from mutated p21 ras (Gln $\rightarrow$ Leu61). Int Immnol 4: 1331 - 1337

Hammer J, Bono E, Gallazzi F, Belunis C, Nagy Z, Sinigaglia F (1994) Precise prediction of major histocompatibility complex class II-peptide interaction based on peptide side chain scanning. J Exp Med 180: $2353-2358$

Harmer PJ, La Vecchio J, Ng S, Delellis R, Wolfe H, Carney WP (1991) Activated Val-12 ras p21 in cell culture fluids and mouse plasma. Oncogene 6: 1609-1615

Jung S, Schluesener HJ (1991) Human T lymphocytes recognise a peptide of single point-mutated, oncogenic ras proteins. J Exp Med 173: $273-276$

Juretic A, Jurgens-Gobel J, Schaefer C, Noppen C, Willimann TE, Kocher T, Zuber M, Harder F, Heberer M, Spagnoli GC (1996) Cytotoxic T-lymphocyte responses against mutated p21 ras peptides: an analysis of specific T-cell-receptor gene usage. Int J Cancer 68: $471-478$

Kawakami Y, Rosenberg SA (1997) Human tumour antigen recognised by T-cells. Immunol Res 16: 313-339

Marx J (1989) Many gene changes found in cancer. Science 246: $1386-1388$

Nakagawa T, Saitoh S, Imoto S, Itoh M, Tsutsumi M, Hikiji K, Nakao Y, Fujita T (1991) Loss of multiple point mutations of ras genes associated with acquisition of chromosomal abnormalities during disease progression in myelodysplastic syndrome. $\mathrm{Br} \mathrm{J}$ Haematol 77: $250-252$

Nestle FO, Alijagic S, Gilliet M, Sun Y, Grabbe S, Dummer R, Burg G, Schadendorf D (1998) Vaccination of melanoma patients with peptideor tumour lysate-pulsed dendritic cells. Nat Med 4: 328-332
Peace DJ, Chen W, Nelson H, Cheever MA (1991a) T-cell recognition of transforming proteins encoded by mutated ras proto-oncogenes. $J$ Immunol 146: 2059-2065

Peace DJ, Smith JW, Chen W, You SG, Cosand WL, Blake J, Cheever MA (1991b) Lysis of ras oncogene-transformed cells by specific cytotoxic T lymphocytes elicited by primary in vitro immunization with mutated ras peptide. J Exp Med 179: 473 - 479

Qin H, Chen W, Takahashi M, Disis ML, Byrd DR, McCahill L, Bertram KA Fenton RG, Peace DJ, Cheever MA, Parkfurst MR, Kawahami Y, Seipp CA, Einhorn JH, White DE (1995) CD4+ T-cell immunity to ras protein in pancreatic and colon cancer patients. Cancer Res 55: 2984-2987

Rammensee HG (1995) Chemistry of peptides associated with MHC class I and class II molecules. Curr Opin Immunol 7: 85-96

Rosenberg SA, Yang JC, Schwarzentruber DJ et al (1998) Immunologic and therapeutic evaluation of a synthetic peptide vaccine for the treatment of patients with metastatic melanoma. Nat Med 4: 321-327

Rudensky AY, Preston-Hurburt P, Jneway Jr CA (1991) Sequence analysis of peptides bound to MHC class II molecules. Nature 353: 622

Suwa H, Yoshimura T, Yamaguchi N, Kanehira K, Manabe T, Imamura M, Hiai H, Fukumoto M (1994) Ki-ras and p53 alteration in genomic DNA and transcripts of human pancreatic adenocarcinoma cell. Jpn J Cancer Res 85: $1005-1014$

Takahashi M, Chen W, Byrd DR, Disis ML, Husby ES, Qin H, Cheever MA (1995) Antibody to ras protein in colon cancer. Clini Cancer Res 1: $1071-1077$

Takeda S, Ichii S, Nakamura Y (1993) Detection of Ki-ras mutation in sputum by mutant-allele-specific-amplification (MASA). Human Muta 2: $112-117$

Tsang KY, Nieroda CA, Defilippi R, Chung YK, Yamaue H, Schlom J (1994) Induction of human cytotoxic T-cell lines directed against point-mutated p21 ras-derived synthetic peptides. Vaccine Res 3: 183-193

Valenzuela DM, Groffen J (1986) Four human carcinoma cell lines with novel mutation in of c-Ki-ras oncogene. Nucleic Acids Res 14: 843-852

van der Bruggen P, Traversari C, Chomez P, Lurquin C, De Plaen E, Van den Eynde B, Knuth A, Boon T (1991) A gene encoding an antigen recognised by cytolytic $\mathrm{T}$ lymphocytes on a human melanoma. Science 254: 1643 - 1647

Vogelstein B, Fearon ER, Hamilton SR, Kern SE, Preisinger AC, Leppert M, Nakamura Y, White R, Smits AM, Bos JL (1988) Genetic alterations during colorectal-tumour development. $N$ Engl J Med 319: 525-531 